ISSN 0258-7122

Bangladesh J. Agril. Res. 40(1): 71-76, March 2015

\title{
YIELD RESPONSE OF SUMMER COUNTRY BEAN TO BORON AND MOLYBDENUM FERTILIZER
}

\author{
SHAMIMA NASREEN ${ }^{1}$, M. A. SIDDIKY ${ }^{2}$, R. AHMED ${ }^{3}$ AND R. P. RANNU ${ }^{4}$
}

\begin{abstract}
Field experiments were conducted in the Grey Terrace Soil (Aeric Albaquept) under AEZ-28 at the Bangladesh Agricultural Research Institute (BARI) farm, Gazipur during summer seasons of 2010 and 2011 to determine the optimum rate of boron and molybdenum combination for maximizing the yield of summer country bean (var. BARI Sheem-3). Four levels each of B $\left(0,1,2\right.$ and $\left.3 \mathrm{~kg} \mathrm{ha}^{-1}\right)$ and Mo $\left(0,0.5,1.0\right.$ and $\left.1.5 \mathrm{~kg} \mathrm{ha}^{-1}\right)$ were used as treatment variables. The results indicated that application of B and Mo fertilizer combination exerted significant influence on the number of pods plant ${ }^{-1}$, individual pod weight and pod yield $\mathrm{ha}^{-1}$ in both the years. The highest pod yield $\left(9.58 \mathrm{t} \mathrm{ha}^{-1}\right.$ in 2010 and $9.42 \mathrm{t} \mathrm{ha}^{-1}$ in 2011) was produced by the combination of $2 \mathrm{~kg} \mathrm{~B}$ and $1.5 \mathrm{~kg} \mathrm{Mo} \mathrm{ha}^{-1}$ and it was statistically identical with $2 \mathrm{~kg} \mathrm{~B}$ and $1.0 \mathrm{~kg} \mathrm{Mo} \mathrm{ha}^{-1}$ combination. Addition of B beyond $2 \mathrm{~kg} \mathrm{ha}^{-1}$ along with higher doses of Mo created a detrimental effect to reduce yield irrespective of years. The results revealed that application of $2 \mathrm{~kg}$ $\mathrm{B}$ and $1 \mathrm{~kg} \mathrm{Mo} \mathrm{ha}^{-1}$ combination with a blanket dose of $50 \mathrm{~kg} \mathrm{~N}, 40 \mathrm{~kg} \mathrm{P}, 60 \mathrm{~kg}$ $\mathrm{K}$ and $20 \mathrm{~kg} \mathrm{Sha}^{-1}$ plus cowdung $5 \mathrm{t} \mathrm{ha}^{-1}$ might be optimum for summer country bean cultivation in Grey Terrace Soil of Gazipur.
\end{abstract}

\section{Introduction}

Country bean (Dolichos lablab) is one of the major vegetables from the Leguminosae family. In addition to the protein contributions of the legume, it is rich in other nutrients such as starch, dietary fiber, protective phytochemicals, vitamins and elements (Saikia et al., 1999). Country bean is grown in Bangladesh during summer and winter seasons. Summer country bean is a newly introduced vegetable crop in this country. The yield of summer country bean is low in Bangladesh as compared to the other countries of the world. The reasons of lower yield can be attributed to imbalanced use of fertilizer and lack of high yielding varieties. The farmers of Bangladesh usually use $\mathrm{N}, \mathrm{P}$ and $\mathrm{K}$ for crop production. Use of micro nutrients is limited. However, boron influenced the absorption of $\mathrm{N}$, $\mathrm{P}, \mathrm{K}$ and its deficiency changed the equilibrium of optimum of those three macronutrients (Raj, 1985). It influences yield and yield attributes of French bean (Singh et al., 1989; Singh and Singh, 1990). Patra (1989) found higher yield in soybean due to application of $\mathrm{B}$ at the rate of $2 \mathrm{~kg} \mathrm{ha}^{-1}$. Molybdenum is an important element to help in protein synthesis and fixation of atmospheric

${ }^{1}$ Chief Scientific Officer, ${ }^{2}$ Senior Scientific Officer, ${ }^{3 \& 4}$ Scientific Officer, Soil and Water Management Section, Horticulture Research Centre, Bangladesh Agricultural Research Institiute (BARI), Joydebpur, Gazipur, Bangladesh. 
nitrogen in the root of legume by nodule bacteria. Singh et al. (2008) reported that application of Mo alone or combination with S. rhizobium significantly increased the grain of blackgram as compared to control. Ruschel et al. (1970) reported that application of molybdenum fertilizer in combination with boron significantly increased bean yield. The influence of Mo and B on different grain legumes have been reported by Bhuiyan et al. (1997) and Chowdhury et al. (1998). Information on the use of B and Mo in combination with NPKS and organic manure for summer country bean cultivation in Bangladesh is scanty. In view of this, field experiments were conducted to determine the optimum rate of $\mathrm{B}$ and Mo combination in presence of NPKS and cowdung for maximizing the yield of summer country bean in Grey Terrace Soil of Gazipur.

\section{Materials and Method}

Field experiments were carried out at the Bangladesh Agricultural Research Institute (BARI) farm, Joydebpur, Gazipur during summer (Kharif) seasons of 2010 and 2011. The soil of the experimental field was loam in texture. It belongs to the Chhiata series of the Grey Terrace Soil (Aeric Albaquept) under the AEZ28 (Modhupur Tract). Results of initial soil analysis are presented in Table 1. The soil test values showed that the experimental soil was deficient in N, P, K, S and B. The soil was slightly acidic. Organic matter content of the soil was very low.

Table 1. Chemical properties of the initial soil sample (average data of years 2010 and 2011).

\begin{tabular}{|c|c|c|c|c|c|c|c|c|c|c|}
\hline \multirow{2}{*}{$\mathrm{pH}$} & \multirow{2}{*}{$\begin{array}{l}\mathrm{OM} \\
(\%)\end{array}$} & $\mathrm{Ca}$ & $\mathrm{Mg}$ & K & \multirow{2}{*}{$\begin{array}{c}\text { Total N } \\
(\%)\end{array}$} & $\mathrm{P}$ & $S$ & $\mathrm{~B}$ & $\mathrm{Fe}$ & $\mathrm{Zn}$ \\
\hline & & \multicolumn{3}{|c|}{ Meq $100^{-1} \mathrm{~g}$ soil } & & \multicolumn{5}{|c|}{$\mathrm{mg} \mathrm{kg}^{-1}$} \\
\hline 6.5 & 0.80 & 0.6 & 0.5 & 0.12 & 0.040 & 8 & 9 & 0.10 & 110 & 1.0 \\
\hline \multicolumn{2}{|c|}{ Critical level } & 2.0 & 0.8 & 0.20 & 0.12 & 14 & 14 & 0.2 & 10 & 0.6 \\
\hline
\end{tabular}

The treatment consisted of four levels each of boron $\left(0,1,2\right.$ and $\left.3 \mathrm{~kg} \mathrm{~B} \mathrm{ha}^{-1}\right)$ and molybdenum $\left(0,0.5,1.0\right.$ and $\left.1.5 \mathrm{~kg} \mathrm{ha}^{-1}\right)$. The treatments were factorial combination of the two factors and the experiment was conducted using randomized complete block design with three replications. The unit plot size was $4 \mathrm{~m} \mathrm{x} 4 \mathrm{~m}$. Thirty day old seedlings of BARI Sheem-3 were transplanted on 28 April, 2010 and 11 May, 2011 at a spacing of $1.5 \mathrm{~m} \times 1.5 \mathrm{~m}$. Boron and molybdenum were applied as boric acid and ammonium molybdate, respectively in the pits. Blanket dose of $50 \mathrm{~kg} \mathrm{~N}, 40 \mathrm{~kg} \mathrm{P}, 60 \mathrm{~kg} \mathrm{~K}$ and $20 \mathrm{~kg} \mathrm{~S} \mathrm{ha}^{-1}$ in the form of urea, triple super phosphate (TSP), muriate of potash (MoP), gypsum and cowdung at $5 \mathrm{t} \mathrm{ha}^{-1}$ were added to every plot. TSP, MoP, gypsum, cowdung and half of urea were applied in the pits as basal and remaining half of urea was applied after third week of transplanting. Intercultural operations such as weeding, irrigation and insecticide spray were done as and when required. Pods of country bean were harvested from each plot during July-August, 2010 and 
July- September, 2011 and recorded. Twenty pods were randomly selected from each plot to record the data on yield components. Weight of total pod $\operatorname{plot}^{-1}$ was recorded to compare per hectare yield. All the data were analyzed by computer using MSTAT-C package and mean values were compared by Duncan's New Multiple Range Test (Gomez and Gomez, 1984).

\section{Results and Discussion}

Results obtained from interaction of B and Mo levels were significant. Hence, only interaction effects on different plant characters arediscussed here. Interaction effects of B and Mo levels were significant in respect of number of pods plant ${ }^{-1}$ and weight of individual pod of summer country bean in both the years (Figs. 1 and 2). Application of B and Mo fertilizer significantly increased the number of pods plant ${ }^{-1}$ with increasing rate for B up to $2 \mathrm{~kg} \mathrm{ha}^{-1}$ and for Mo up to $1.5 \mathrm{~kg} \mathrm{ha}^{-1}$ combination and it was statistically identical with $2 \mathrm{~kg} \mathrm{~B} \mathrm{ha}^{-1}$ and $1.0 \mathrm{~kg}$ Mo ha ${ }^{-1}$ combination in both the years. These two treatments, however, were significantly different from all other treatment combinations. Number of pods plant ${ }^{-1}$ varied from 161 to 392 in 2010 and 157 to 388 in 2011 due to different combination of $\mathrm{B}$ and Mo. The higher levels of $\mathrm{B}$ and Mo fertilizers in combination significantly reduced the number of pods plant ${ }^{-1}$ irrespective of years. The lowest value was recorded from $\mathrm{B}_{0} \mathrm{Mo}_{0}$ treatment. Almost similar trend of variations in respect of weight of individual pod was noticed due to interaction of B and Mo fertilization. The results thus indicate that B and Mo fertilizers along with NPKS and cowdung played key role to enhance pods plant ${ }^{-1}$ and weight of unit pod to a considerable extent.Boron and molybdenum levels also interacted significantly with respect to pod yield ha $^{-1}$ (Fig. 3). Pod yield differed from 4.14 to $9.58 \mathrm{t} \mathrm{ha}^{-1}$ in 2010 and 3.97 to $9.42 \mathrm{t} \mathrm{ha}^{-1}$ in 2011 due to different levels of $\mathrm{B}$ and Mo combination. The highest pod yield (9.58 tha $\mathrm{th}^{-1}$ in 2010 and $9.42 \mathrm{tha}^{-1}$ in 2011) of summer country bean was achieved with the combined application of $2 \mathrm{~kg} \mathrm{~B}$ and $1.5 \mathrm{~kg} \mathrm{Mo} \mathrm{ha}^{-1}$ in presence of $50 \mathrm{~kg}$ $\mathrm{N}, 40 \mathrm{~kg} \mathrm{P}, 60 \mathrm{~kg} \mathrm{~K}, 20 \mathrm{~kg} \mathrm{~S}^{-1}$ and cowdung at $5 \mathrm{t} \mathrm{ha}^{-1}$ and it was statistically identical with $2 \mathrm{~kg} \mathrm{~B}$ and $1.0 \mathrm{~kg} \mathrm{Mo} \mathrm{ha}^{-1}$ combination in both the years. These two treatment combinations were significantly different from all other treatment combinations. The soil test value showed that experimental field was highly deficient in different nutrients. Application of B and Mo along with other essential nutrients to the soil helped in maintaining soil fertility and offered favorable response, which was reflected by higher yield. Moreover, supply of 2 $\mathrm{kg} \mathrm{B}$ and $1.5 \mathrm{~kg}$ Mo ha ${ }^{-1}$ combination in presence of NPKS and cowdung for better growth and plant development which resulted in higher yield due to higher pods plant $^{-1}$ and pod weight.Similar finding was obtained by Shil et al. (2007). 
They reported that combined application of B and Mo provided a beneficial effect on seed yield of chickpea. The beneficial effect of the combined application of B and Mo including $\mathrm{Zn}$ has been reported with chickpea grown in calcareous soil (Jahiruddin, 2008) and also with French bean (Kushwaha, 1999). Addition of B level beyond $2 \mathrm{~kg} \mathrm{ha}^{-1}$ along with higher dose of Mo created a detrimental effect to reduce yield irrespective of years. The negative response of higher dose of $\mathrm{B}$ and Mo in the experiment might be due to imbalance caused by increasing level B and Mo without concomitant increase in other fertilizer. The results showed that yield of summer country bean increased with the increase of $\mathrm{B}$ and Mo application upto a certain limit. Plants grown without B and Mo $\left(\mathrm{B}_{0} \mathrm{Mo}_{0}\right)$ gave the lowest pod yield of $4.14 \mathrm{t} \mathrm{ha}^{-1}$ in 2010 and $3.97 \mathrm{t} \mathrm{ha}^{-1}$ in 2011.

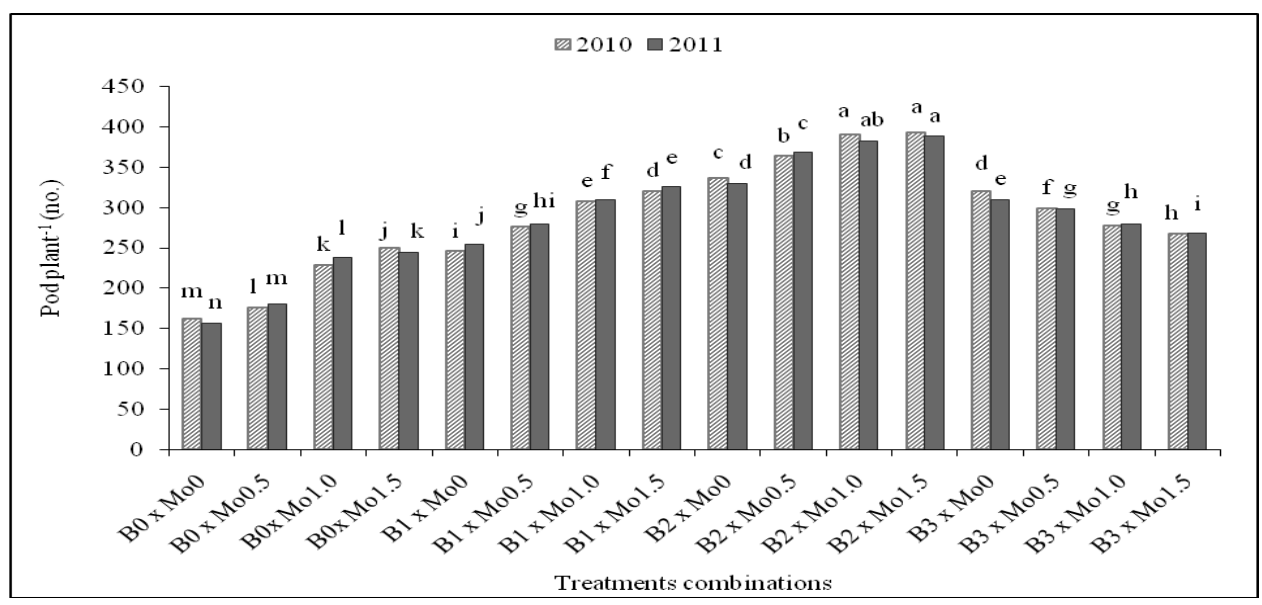

Fig. 1. Interaction effect of boron and molybdenum on the pods plant ${ }^{-1}$ of summer country bean.

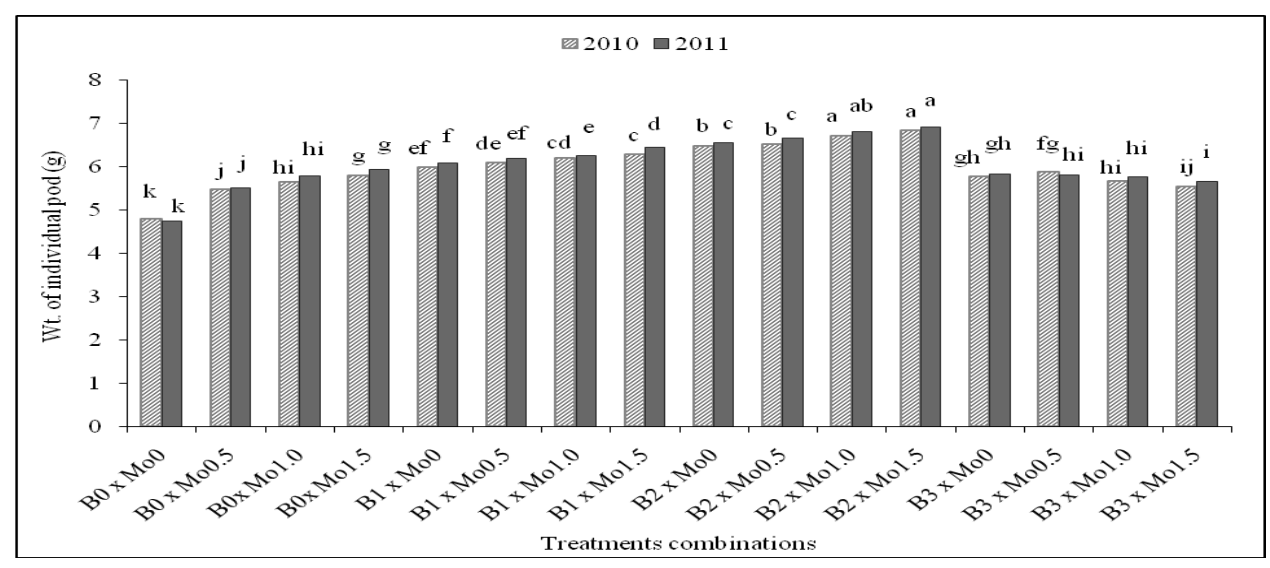

Fig. 2. Interaction effect of boron and molybdenum on the weight of individual pod of summer country bean 


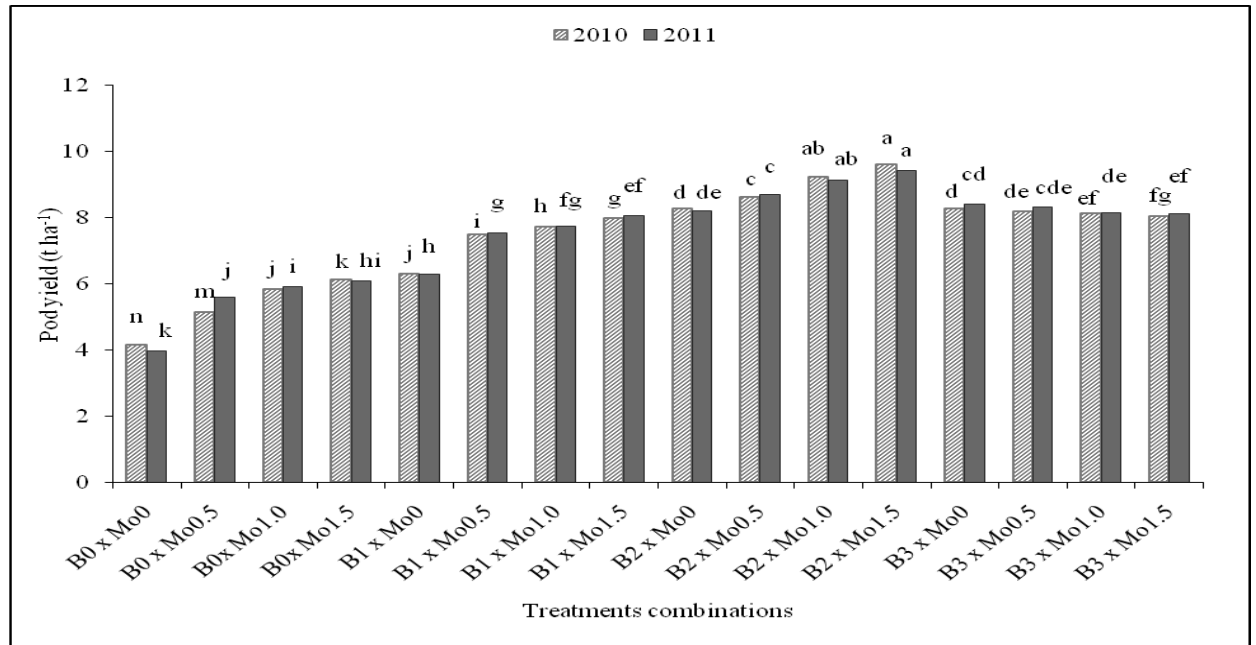

Fig. 3. Interaction effect of boron and molybdenum on the pod yield ha ${ }^{-1}$ of summer country bean

\section{Conclusion}

Results of two years reveal that there exists a scope for yield improvement of summer country bean by application of B and Mo. Application of $2 \mathrm{~kg} \mathrm{~B}$ and 1 $\mathrm{kg} \mathrm{Mo} \mathrm{ha}{ }^{-1}$ combination in presence of $50 \mathrm{~kg} \mathrm{~N}, 40 \mathrm{~kg} \mathrm{P}, 60 \mathrm{~kg} \mathrm{~K}, 20 \mathrm{~kg} \mathrm{~S}^{-1}$ and cowdung at $5 \mathrm{t} \mathrm{ha}^{-1}$ for BARI Sheem-3 might be optimum for obtaining maximum pod yield in Grey Terrace Soil (AEZ-28) of Gazipur.

\section{References}

Bhuiyan, M. A. H., D. Khanam, M. H. H. Rahman and A. K. M. Hossain. 1997. Influence of Rhizobium inoculums, molybdenum and boron on chickpea in Grey Terrace Soil of Bangladesh. Ann. Bangladesh Agric. 7(2): 119-126.

Chowdury, M. U., M. H. Ullah, M. A. Afzal, D. Khanam and S. M. Nabi. 1998. Growth, nodulation and yield of cowpea as affected by Rhizobium inoculums and micronutrients in the hilly region. Bangladesh J. Agric. Res. 23(2): 195-203.

Gomez, K. A. and A. A. Gomez. 1984.Statistical Procedures for Agricultural Research. $2^{\text {nd }}$ edition, John Wiley \& Sons, Newyork, USA. Pp. 860.

Jahiruddind, M., 2008.Role of micronutrients in balanced fertilization for sustainable crop production in Bangladesh. Bangladesh J Agric. Environ. 4:165-175.

Kushwaha, B.L., 1999. Studies on response of frenchbean to zinc, boron and molybdenum application. Indian J. Pulses Res. 12: 144-148.

Patra, A. R. 1989. Productivity of soybean as affected by different micronutrients. Envir. And Ecol. 16(4): 763-764.

Raj, S. 1985. Groundnut.An introduction to physiology of field crops.Oxford and IBH publishing Co., New Delhi. Pp. 94-97. 
Ruschel, A. P., A. C. Dem. Rocha and A. Def. Pen-Teado.1970. Effect of B and Mo applied to different seed coating of bean (Phaseolus vulgaries). Pesquisa Agropecuaria Brasileira 5: 49-52.

Saikia, P. C., C. R. Sarker and I. Boura. 1999. Chemical composition, anti-nutritional factors and effect of cooking on nutritional quality of rice bean (Vigna umbellate). Food Chemistry 67: 347-352.

Shil, N.C., S. Noor and M.A. Hossain. 2007. Effects of boron and molybdenum on the yield of chickpea. J. Agric. Rural Develop. 5: 17-24.

Singh, B. P. and B. Singh. 1990.Response of French bean to phosphorus and boron in acid Alfisols in Meghalaya. J. Indian Soc. Soil Sci. 38(4): 769-771.

Singh, B. P., B. Singh and B. N. Singh. 1989. Influence of phosphorus and boron on picking behavior and quality of French bean (Phaseolus vulgaris L.) under limited irrigation, grown in Alfisol deficient in P and B. Indian J. Agric. Sci. 59(8): 541-543.

Singh, R. P., J. S. Bisen, P. K. Yadav, S. N. Singh, R. K. Singh, and J. Singh. 2008. Integrated use of sulphur and molybdenum on growth, yield and quality of blacgram (Vigna mungo L.). Legume Res. 31(3): 214-217. 